\title{
ARTIKEL
}

\section{Notariële ambtsethiek als constante in de opleiding van de notaris: de deugd in het midden}

\author{
Special issue on Education in (Professional) Legal Ethics, \\ Emanuel van Dongen \& Jet Tigchelaar (eds.)
}

Boudewijn Waaijer*

\begin{abstract}
Behandeld wordt de vraag of en hoe door educatie een bijdrage kan worden geleverd aan beroepsethisch handelen in het notariaat. Ik doe dat door de opleidingseisen te differentiëren al naar gelang de verschillende gedaanten die de notarieel jurist aanneemt: die van student, beginnend notarieel jurist en notarieel jurist met een afgeronde beroepsopleiding.
\end{abstract}

Keywords: education, notaries, legal ethics.

'Het niet naleven van fatsoensregels schaadt het aanzien van het notariaat als geheel. Algemene regels zijn niet altijd te geven aangezien de omstandigheden voor het bepalen van de geoorloofdheid van een handelen of nalaten mede gewicht in de schaal leggen. Soms zal in niet geheel duidelijke situaties een afweging moeten worden gemaakt. Daarbij moet wel in het oog worden gehouden, dat het karakter van het ambt met zich brengt dat regels die gelden voor een goede beroepsuitoefening op velerelei gebied strenger zullen zijn dan die welke voor andere beoefenaars van vrije beroepen gelden. De vroeger wel spreekwoordelijke lijdelijkheid van de notaris is bijvoorbeeld een betrekkelijke.' - Heuff, 1993, p. 68

\section{Inleiding; nieuwe tijden, nieuwe aandacht}

\subsection{Maatschappelijke veranderingen}

Beroepsethiek leeft. Meer en meer wordt ook aandacht gevraagd voor de notariële, ambtsethische aspecten van het doen en laten van de professionals uit het notariaat. Dat is ook wel verklaarbaar. Het notariaat heeft zich als product van de samenleving ontwikkeld, zoals dat ook is gebeurd met bijvoorbeeld de advocatuur en de gerechtsdeurwaarderij. De notaris oefent een ambt uit; hij bekleedt staatsgezag. Dat wordt duidelijk geillustreerd door de typerering van de notaris als bestuursorgaan in de zin van de Algemene wet bestuursrecht (art. 1 lid 1 sub b Awb). Als amb-

* Mr. dr. Boudewijn Waaijer is Of counsel bij Dentons Europe LLP, Amsterdam. 
tenaar is hij evenwel atypisch in die zin, dat hij niet in dienst is van de overheid. De notaris vergaart zijn inkomen als ondernemer. ${ }^{1}$ Aanvankelijk was dat ondernemerschap relatief. Voor bepaalde verrichtingen bestonden domeinmonopolies en diende de notaris zijn daarop betrekking hebbende werkzaamheden te verrichten tegen vaste, door de wetgever voorgeschreven tarieven. ${ }^{2}$ Later werden tarieven grotendeels voorgeschreven door de beroepsorganisatie Koninklijke Notariële Beroepsorganisatie (KNB). Dat honorarium werd maatschappelijk als te hoog ervaren en als medicijn daarvoor werd marktwerking ingezet. Met de recente opkomst van het neo-liberale marktdenken is de nadruk verschoven van het ambtelijk optreden tegen vaste vergoedingen naar die van marktpartij werkend tegen in onderling overleg te bepalen beloningen. Dat is een bewuste keus geweest in de politiek. Net als bij de gerechtsdeurwaarders, werd meer marktwerking noodzakelijk geacht om onder meer een betaalbare toegang tot de notariële dienstverlening af te dwingen. ${ }^{3}$ Met de ingrijpende aanpassingen in de Wet op het notarisambt (Wna) van 1999 werd de notaris dus gedwongen meer als marktpartij te opereren. De reclameborden langs het hockeyveld en participatie aan marktinitiatieven als het HEMAtestament en het Kruidvat-samenlevingscontract zijn daar uitingen van.

Naast het overheidsstreven de financiële toegankelijkheid van het notariaat te waarborgen door marktwerking voor te schrijven, zijn er stellig andere oorzaken aan te wijzen die de aandacht voor de ambtsethische aspecten van de notariële dienstverlening hebben vergroot. Het maatschappelijke streven naar transparantie en de digitale revolutie die is ontketend door het internet, hebben ook het notariaat onder de loep gelegd. Daarmee is zichtbaarder geworden hoe de notaris zich gedraagt. Uitwassen en incidenten worden vol in het licht gezet. Of komt er vandaag de dag gewoonweg meer boven water?

Wat daarvan zij, door dit alles werd het ambt van notaris in zekere zin 'ontheiligd'. Het is niet langer een officium nobile, maar een 'gewoon' vrij beroep. De notaris is van zijn sokkel getrokken, hij is 'ontsokkeld'.

Blijft die notaris dan wel onkreukbaar? De maatschappij eist een verantwoord handelend notariaat. De vraag is hoe het goede in het handelen van de notaris behouden blijft of versterkt wordt onder grilliger economische marktomstandigheden. Meer aandacht hebben voor beroeps-, of liever ambtsethiek, voor notarissen lijkt, nee, is geboden.

\subsection{Ambtsethiek door de jaren heen}

Dat aandacht voor ambtsethiek niet van vandaag of gisteren is, is evident. Die aandacht werd vooral geconcretiseerd door het tuchtrecht. Het was de tuchtrechter, die lang als enig of ten minste belangrijkste loods leek te fungeren over de weging van notarieel handelen. Binnen de notariële opleiding bleef gestructureerde aandacht voor ambtsethiek en meer in het bijzonder het tuchtrecht lange tijd schaars, zo niet afwezig. Illustratief is wat A.H.M. Santen, bijzonder hoogleraar Notarieel

$1 \quad \mathrm{Al}$ zijn er voorzichtige mogelijkheden geopend zoals notaris zijn in loondienst van een ander, een notaris wel te verstaan. Ik denk aan de toegevoegd notaris.

2 Vide de zogeheten Tariefwet, Wet van 31 maart 1847, Stb. 12.

3 Voor die ontwikkeling bij de gerechtsdeurwaarders: Van den Berg-Smit, 2013.

4 De ontwikkeling is fraai en veel uitgebreider beschreven door Lekkerkerker, 2010. 
recht aan de Universiteit van Amsterdam met aandacht voor deontologie voor het notariaat, in 1992, optekende in een opstel in WPNR: 'Er zijn tot 1980 generaties beroepsgenoten geweest die van het bestaan van het tuchtrecht slechts terloops hadden vernomen van hun opleider of hun docent (ik heb er Pitlo nooit over gehoord; Buikema behandelde de hele notariswet in twee middagen) die daarmee in aanraking kwamen als het te laat was (...)' (Santen, 1992, 466).

De aandacht voor ambtsethiek van buiten het notariaat nam toe vanaf de jaren zeventig van de vorige eeuw. Het was de pers die indringend aandacht besteedde aan misstanden, waardoor het maatschappelijk gevoelen geopenbaard werd. ${ }^{5} \mathrm{Na}$ de ingrijpende wetswijziging van de Wna van 1999, ontstond er meer geïnstitutionaliseerde aandacht voor notariële ambtsethiek. In dat verband kan worden gewezen op het rapport van de Commissie Evaluatie Wet op het Notarisambt (2005). Daarin laat de commissie in hoofdstuk 9 bij wijze van conclusie en aanbeveling optekenen dat deze geen eenduidig beeld heeft over tot de ambtelijke ethiek.

'Enerzijds worden signalen gehoord dat sommige notarissen de grenzen van de ethiek van het ambt opzoeken, anderzijds heeft de commissie geen harde aanwijzingen gevonden dat de kwaliteit van de dienstverlening tekort zou schieten. De vrees bestaat dat door de concurrentie hier en daar van verschraling van kwaliteit sprake is. Bij een onderzoek naar de ambtelijke aspecten (de meetbare kwaliteit van de akten) zijn geen verontrustende gegevens naar boven gekomen. De commissie acht het wenselijk dat het ministerie van Justitie en de KNB nader onderzoek doen naar de kwaliteit en de integriteit van de notariële dienstverlening.'

Dat onderzoek heeft dan ook van overheidswege plaatsgevonden. ${ }^{6}$ In het kielzog van onderzoek door de overheid, kreeg de notariële ambtsethiek ook aandacht vanuit de wetenschap. ${ }^{7}$ De aandacht van buiten het notariaat is goed, maar een verbeterde ambtsethiek zal toch in de eerste plaats van het notariaat zelf moeten komen. Zo zijn concrete vraagtekens gezet bij de corrumperende werking van de markt op het functioneren van het notariaat (Waaijer, 2013).

Het zal niet de stok zijn die werkelijk verbetering brengt, maar de wortel. Is binnen het notariaat vandaag de dag voldoende aandacht voor ambtsethiek? In dit artikel stel ik de vraag of en hoe een bijdrage kan worden geleverd aan beroepsethisch handelen in het notariaat door educatie. Ik doe dat door een mijns inziens noodzakelijke differentiatie voor de opleidingseisen aan te brengen, al naar gelang de verschillende gedaanten die de notarieel jurist aanneemt: die van student, be-

$5 \quad$ Ik denk hierbij aan geruchtmakende affaires rond notarissen in het vastgoed (onder meer in Den Haag), waarover Vrij Nederland in een reeks van zes publicaties in 1979 verslag deed. De impact van die verslaggeving mag, ook binnen het notariaat, niet onderschat worden.

6 Ik noem de Trendrapportages notariaat van het WODC en de rapportages van de Commissie Monitoring Notariaat.

7 Genoemd kunnen worden: Kocken, 1997 en met meer specifieke aandacht voor ambtsethiek: Lacklé, 2008. Laatstgenoemde auteur werkte eerder voor het WODC aan rapporten over het notariaat. 
ginnend notarieel jurist en die als notarieel jurist met een afgeronde beroepsopleiding.

\section{Ambtsethiek voor notarieel juristen: binnen en buiten het juridische kader}

\subsection{Ambtsethiek voor notarieel juristen: de regelethiek}

Laten we het gemakshalve maar platslaan: met ambtsethiek wordt gedoeld op het goede doen in de professionele uitoefening van het beroep of, zoals het voor de notaris moet worden geformuleerd, het ambt van notaris. Vanuit een oogpunt van ordening essentieel is voor iedere educatie, is het zinvol een onderscheid te maken tussen wat ik zou willen noemen 'gestolde ethiek' en 'vloeibare ethiek'.

Ambtsethiek is normaliter voor een niet onbelangrijk deel gestold in regelgeving. Zo kunnen op diverse plaatsen in de Wna normen voor ethisch handelen worden gevonden. Als het gaat om de tuchtrechtspraak is in artikel 93 Wna te lezen dat notarissen, toegevoegd notarissen en kandidaat-notarissen aan tuchtrechtspraak zijn 'onderworpen ter zake van handelen of nalaten in strijd met hetzij enige bij of krachtens deze wet gegeven bepaling, hetzij met de zorg die zij als notaris, toegevoegd notaris of kandidaat-notaris behoren te betrachten ten opzichte van degenen te wier behoeve zij optreden en ter zake van handelen of nalaten dat een behoorlijk notaris, toegevoegd notaris of kandidaat-notaris niet betaamt'. Een algemene norm als deze, in iedere tuchtrechtuitspraak als vertrouwde stopnaald te vinden, biedt geen enkele richting voor concrete situaties. Vaak wordt al meer houvast geboden door andere artikelen uit de Wna en door regelgeving in Verordeningen, zoals de in dit verband zo belangrijke Verordening Beroeps- en gedragsregels 2011. Ook de tuchtrechtuitspraken en de uitspraken van de civiele rechter die zien op het gedragsrecht van de notaris, zou ik willen scharen onder gestolde ethiek. ${ }^{8}$ In die regelgeving en jurisprudentie komt tot uiting hoe te handelen.

Anders dan menig leek meent, is het lastig genoeg om op basis daarvan in concrete gevallen het goede te destilleren. Dat moet gebeuren op basis van feiten, die altijd anders zijn dan die de wetgever of rechter bij eerdere uitspraken onder ogen had. Ook dient de notaris vaak beslissingen te maken onder lastige omstandigheden. Niet zelden dient de notaris te oordelen in gevallen waarin hij onder druk staat: druk van partijen of, tijdsdruk (Waaijer, 2017a). Ook staat het hem niet altijd vrij het onderzoek te doen dat hij wellicht zou willen doen. ${ }^{9}$ Bovendien schuilt

8 Ik schaar de bijdragen van de rechter bewust onder de regelethiek en blijf zijn taak daarmee zien binnen de kaders van het recht. De meningen kunnen erover verschillen of de rechter die grenslijn onder omstandigheden niet zou moeten passeren. Zie Soeharno, 2020, 942 e.v. Een voorbeeld van gedragsrechtelijke jurisprudentie van de civiele rechter is te vinden in HR 17 januari 2020, ECLI: NL:HR:2020:61, Moet een advocaat zorg hebben voor de belangen van derden?, met annotatie B.C.M. Waaijer in AA 2020/06.

9 In HR 3 april 2015, ECLI:NL:HR:2015:831 (Novitaris), bepaalde de Hoge Raad dat de geheimhoudingsplicht de notaris belette zijn licht op te steken bij een derde, als dat niet de instemming had van partijen. 
in ieder jurist een legist. Dit alles neemt niet weg dat dit onderzoeksveld zeer relevant is. En blijft. ${ }^{10}$

\subsection{Intermezzo}

Regelethiek richt zich op het handelen van de mens binnen de samenleving en is gericht op de ordening daarvan. Naarmate de reikwijdte van een regel en de daarop gebaseerde jurisprudentie meer en meer haar grenzen bereikt, hoe dat ook voor juristen kan verschillen, lijkt het erop dat we ons niet uitsluitend kunnen verlaten op de regelethiek. Ik zeg het bewust voorzichtig, want de regelethiek kan veel ruimte bieden voor het goede. ${ }^{11}$

Wie de regelethiek verlaat, komt in domeinen waarin hij gemakkelijk verdwaalt. Niettemin is het zinvol om bewustheid te kweken dat mogelijk grensoverschrijdingen in beeld komen die al dan niet noodzakelijk zijn.

\subsection{Ambtsethiek buiten de vertrouwde juridische kaders?}

Als de grenzen van het juridisch domein bereikt lijken te zijn, wint het belang van andere, meer algemene ethiek als mogelijke reddingsboei voor concrete gevallen aan kracht. Hulp of ten minste inspiratie kan bijvoorbeeld worden gevonden bij de klassieke, christelijke of hedendaagse deugdethiek, ${ }^{12}$ de gedachten van Kant, van de utilisten en van zovelen anderen. De ambtsethiek bijvoorbeeld, vraagt aandacht die de beroepsbeoefenaar niet altijd binnen de hem vertrouwde kaders van wetboek, jurisprudentieverzamelingen en juridische literatuur tot zich kan nemen. Beroepsethische kwesties dus, waarvoor die 'ankers' geen of onvoldoende houvast bieden. En die kwesties zijn er genoeg. Het gaat dan om vragen die nauwelijks nog tot gestolde ethiek kunnen worden herleid. Hier wordt het voor de wetenschappelijk geïnteresseerde ethici juist leuk, maar doemen voor de praktijkjuristen visioenen op van zompige en mistige moerasvelden, waarin 'ze het maar uit moeten zoeken'. Juristen worden tijdens hun studie en praktijkuitoefening toch in de eerste plaats - begrijpelijkerwijs - opgeleid met de wet- en andere regelgeving als kader voor oordelen, de jurisprudentie als logisch sequeel, en vakliteratuur als slotakkoord. Dit ondanks onvermoeibare aandacht voor de geest van de wet, redelijkheid en billijkheid, goede trouw, uitleg enzovoort. Juist buiten die vertrouwde grenzen wordt het lastig een goede gids te zijn voor ambtsethiek. Juist hier ligt de uitdagende opgaaf voor opleiders.

10 Een mooi voorbeeld van de aandacht die daarvoor in de literatuur bestaat, vind ik het artikel van Roes, 2017.

11 Er zijn juristen die heel veel vrijheid nemen om de gewenste oplossingen binnen het juridische speelveld te vinden. H.F.C. Schoordijk was zeker zo'n jurist, een jurist met veel gezag. Van hem staat mij de uitspraak bij, dat wie als jurist binnen het wettelijk kader geen rechtvaardige uitkomst vindt, niet goed zoekt; hij moet verder en beter graven. Zie over hem onder meer Stokkermans, 2019.

12 Over het onderscheid tussen regelethiek en deugd(en)ethiek speciaal in het kader van het notarieel recht: Van Mourik, 2008, par. 3.3. Van Mourik verlaat zich op onder meer Paul van Tongeren, door o.a. te verwijzen naar diens Deugdelijk leven, een inleiding in de deugdenethiek. Interessant en toegankelijk blijven de beschouwingen van de filosoof M.J. Sandel over moderne deugdenethiek; ik verwijs naar zijn nog altijd mooie Sandel, 2010. . 


\subsection{Ambtsethiek buiten de juridische kaders: deugdethiek}

Laat ik de handschoen oppakken, en enkele verkennende opmerkingen plaatsen vanuit de deugdethiek, waarbij evident is dat andere ethische invalshoeken mogelijk zijn.

Ik doe dat door met in de deugdethiek zo belangrijke voorbeelden te komen, en daarmee te illustreren wat ethiek zou kunnen bijdragen (Van Tongeren, 2008). Om te beginnen heb ik het oog op de gevallen waarin bijzondere omstandigheden juist nopen om bestaande regels te negeren. Ik denk aan procedureel op correcte wijze tot stand gekomen regels van de bezetter, die in de Tweede Wereldoorlog handelen voorschreven of faciliteerden, waar dat handelen ontrechting van Joodse medeburgers bewerkstelligde. Daarmee werd dus indringend de vraag opgeworpen of het notariaat zich van dienstverlening die ontrechting mogelijk maakte diende te onthouden (Schütz, 2016). ${ }^{13}$ Met de actuele Covid-19-pandemie denk ik ook aan de bewuste overtreding van voorschriften die notarissen en gerechtsdeurwaarders ${ }^{14}$ voorschrijven hun werk te doen door persoonlijke ontmoetingen met hun cliënten. Mochten die regels met voeten getreden worden? Recht tegen de regel in dus, althans in de periode vóórdat de wetgever of rechter zich daarover uitsprak. Maar hoezeer de betekenis van ethiek in die exceptionele situaties ook spreekt, ook in de praktijk van alledag is ethiek relevant en in ieder geval regelmatiger toepasbaar. Veel vaker zullen omstandigheden voorkomen waarin de vraag rijst of regels genegeerd moeten worden die minder extreem zijn dan oorlogsomstandigheden of tijden van pandemie.

Zeker zo interessant is het terrein waar de klassieke vraag opkomt of alles mag wat niet verboden is. Ook hiervan geef ik ter illustratie een voorbeeld. Voor notarissen vind ik het volgende geval instructief, mede omdat het uit het leven is gegrepen. Normaliter kan een onroerende zaak niet in appartementsrechten worden gesplitst, zonder dat de rechthebbende beschikt over een van overheidswege verstrekte vergunning. Toen nieuwe wetgeving in werking trad, noodzaakte die ook tot regelgeving op gemeentelijk niveau. Niet iedere gemeente was daarvan doordrongen. De gemeente Amsterdam was te traag en als gevolg daarvan vielen voorschriften weg die daar noodzaakten tot het verkrijgen van de vergunning. Voor menig huiseigenaar was dat vacuüm het moment om over te willen gaan tot de splitsing van onroerende zaken in appartementsrechten. Een vergunning was immers niet meer voorgeschreven. Is het dan rechtvaardig dat Amsterdamse notarissen hun diensten verlenen? En als het antwoord nee zou zijn, laat het recht de notaris dan toe zijn eigen morele standaarden op te leggen aan cliënten? (Meer daarover in Waaijer, 2017b, par. 6.4.) Voor richtsnoeren voor dergelijk handelen zullen we mede ons toevlucht tot algemener ethische richtlijnen moeten nemen. Tot spijt van de practici ontbreekt hier het houvast van de hard and fast rules.

Dergelijke vraagstukken van meer vloeibare ethiek zullen beantwoord moeten worden zonder dat daarover op geïnstitutionaliseerde wijze besloten is. Hier kan geen steun meer gevonden worden over hoe het goede te doen in de uitkomsten

13 Minder kritisch over de rol van het Nederlandse notariaat in de oorlog is Van den Boomgaard, 2019, 546, al is haar onderzoeksonderwerp beperkter.

14 HR 19 juni 2020, JOR 2020/225, met noot Steneker: mag een deurwaarder onder Corona omstandigheden een exploot zonder persoonlijk contact betekenen? 
van democratische wetgevingsprocessen of van wettelijke procedures op basis van de Wna over de vaststelling van verordeningen en reglementen. Evenmin is voorhanden het baken van (tucht)uitspraken. Zo'n uitspraak is de resultante van beraadslaging tussen rechters in de meervoudige raadkamer. Die rechters hebben zich tijdens een zitting kunnen laten voorlichten door de raadslieden van partijen. $\mathrm{Zij}$ zullen vervolgens in betrekkelijke rust tot een weging van de argumenten komen, en kunnen ten slotte tot een uitspraak komen.

Onder die omstandigheden zal de beroepsbeoefenaar echter solitair zijn weg moeten vinden (waarbij de deugdethiek hem wellicht enigszins kan helpen). Hij wordt teruggeworpen op zijn eigen gedachten en in het beste geval ook op informeel collegiaal overleg, overleg met beroepsorganisatie KNB, advocaten of op de niet of veel minder op de concrete beroepsuitoefening toegesneden gedachten van ethici. Hoe dan ook is het alleen hij die zelfstandig verantwoordelijk is en wordt gehouden voor zijn eigen doen en laten.

\subsection{Ambtsethiek voor iedere notarieel jurist}

Natuurlijk is het niet zo dat ieder dilemma dat op het bord van de notariële jurist terechtkomt binair moet worden opgelost door ofwel regelethiek ofwel daarbuiten, in de deugdethiek en in andere ethische denkrichtingen. Niet zelden zal een antwoord in beide denkwerelden gevonden worden. Dat is natuurlijk ook het mooiste. Ik denk daarbij aan het geval dat een notaris de opdracht ontvangt een testament te maken voor een oud persoon. Daarbij wordt aangegeven dat die testateur ingrijpend wenst af te wijken van dat wat geldt indien er geen testament wordt gemaakt. Hij wil bijvoorbeeld zijn echtgenoot of een kind onterven. Het notariaat wordt al enige tijd indringend gewezen op de noodzaak dat een notaris zich er terdege van vergewist dat de testateur zijn wil op juridisch relevante wijze kan uiten. En terecht! Menig tuchtrecht- en civiele procedure heeft deze kwestie tot onderwerp en verschillende notarissen zijn hierover terechtgewezen. Er zijn notarissen die hun handen liever niet aan dergelijke opdrachten branden. Wat doet nu de notaris die de vraag voor zich krijgt om dit testament te maken in de situatie dat hij bedrijfsmatig geen enkele noodzaak voelt de opdracht aan te nemen (zijn kantoor doet het bedrijfseconomisch goed)? Wijst hij de testateur op oneigenlijke gronden af (te druk, mijn expertise ligt op andere rechtsgebieden, ons kantoor doet geen familierecht) en adviseert hij deze een collega in de arm te nemen, waarna hij met een gerust hart een ongecompliceerde andere opdracht afhandelt? Of gaat hij de uitdaging aan omdat hij vindt dat ook de testeervrijheid van deze persoon gerespecteerd dient te worden? Dit dilemma kan vanuit de regelethiek worden opgelost door de notaris indringend te wijzen op zijn ministerieplicht zoals vastgelegd in artikel 21 lid 1 Wna. De vraag is niettemin of de notaris de norm die de wet hem hier voorhoudt enkel om de reden dat die is vastgelegd in een regel, zal naleven. De pakkans is hier klein: welke cliënt zal hier een punt van maken? De cliënt zal zijn testament ook wel elders kunnen maken. Bijvoorbeeld de deugdethiek zou de notaris hier de goede richting op kunnen helpen. Vanuit die deugdethiek kan bij deze notaris de houding worden ontwikkeld dat hij de testateur dient te helpen. De deugden rechtvaardigheid en moed kunnen daarbij ter inspiratie dienen. (Over moed ook: Van Domselaar, 2017 en Waaijer, 2020.) 
Hoe kan onderwijs helpen de weg te vinden naar het goede in de ambtsuitoefening? Dat onderwijs vindt plaats op de universiteit maar in mijn ogen zeker zo belangrijk is de educatie in de praktijk.

\section{De universiteit is om te zaaien}

\subsection{Aandacht voor ambtsethiek binnen een overvol studieprogramma}

Eerst de universiteiten. De notariële opleiding is door de wetgever ingesnoerd in een strak korset. Met de overgang naar de bachelor/master-opleiding is de studieduur verkort van vijf naar vier jaar - dat is voor notarieel recht kort - en dat wordt betreurd. Het Besluit op het notarisambt schrijft nauwkeurig vereisten voor de notariële opleiding voor. ${ }^{15}$ Daarin moet veel worden behandeld, onder meer 'grondige kennis van en inzicht in het recht met betrekking tot het notariaat, in het bijzonder de wet'. Gewoonlijk gebeurt dat binnen vakken die namen dragen als Notariële ambtsuitoefening, Notariswet of Notaris en maatschappij. Het is primair dat aandachtsgebied dat gedachten oproept over reflectie inzake de taak en functie van de notaris in het rechtsverkeer: waarom is de notaris op aarde?

Het is gemakkelijk roepen dat er meer aandacht voor ambtsethiek moet komen binnen de notariële, universitaire opleiding. Die aandacht zal dan ten koste moeten gaan van andere, ook belangrijke onderwerpen. Als er meer aandacht moet komen voor ambtsethiek, zal de beschikbare tijd voor bestaande vakken afnemen. En dat terwijl sommigen nu al roepen dat andere aandachtsgebieden in de opleiding zouden moeten worden ingepast, zoals (meer) mediation en conflictbeheersing en rechtspsychologie. Het is dus al dringen geblazen om een plek binnen het curriculum te bevechten.

Ik denk dat het niet gaat om meer studiepunten en dus tijd voor ambtsethiek binnen de opleiding, al zou dat zonder meer helpen. Mijns inziens gaat het vooral over de wijze waarop aandacht besteed moet worden aan ambtsethiek.

Het is overbodig te benadrukken dat het studenten gewoonlijk volstrekt ontbreekt aan relevante beroepservaring. Zij zullen zich dan ook moeilijker dan practici kunnen inleven in de omstandigheden waaronder beroepsethische vragen opkomen. Economische tegenspoed waardoor de bedrijfsresultaten van het notariskantoor onder druk komen te staan, werkdruk en ingesleten werkprocessen ('zo doen we het altijd'), doen stuk voor stuk niet af aan de opdracht van beroepsethisch zuiver handelen. Studenten zullen echter bij gebrek aan werkervaring onvoldoende inlevingsvermogen hebben om de kaders voor ogen te halen waarbinnen het goede pad moet worden bewandeld. Die omstandigheden moeten aanzetten tot extra waakzaamheid. Een dilemma op het gebied van ambtsethiek wordt zelden aangekondigd, het duikt op tussen de bedrijven door. Dat vraagt om het aanscherpen van het bewustzijn.

Toch neemt dat niet weg dat van studenten aandacht voor beroepsethische dilemma's kan en moet worden gevraagd. Idealiter wordt dat gedaan door docenten die de genoemde praktijkomstandigheden kennen. Die aandacht moet dan zo- 
veel mogelijk worden geïncorporeerd in de verschillende vakken, dus idealiter niet uitsluitend, geconcentreerd in het vak Notariële ambtsuitoefening, maar juist ook in alle andere vakken worden ingepast. Ambtsethiek is in de volle breedte van het ambt van betekenis.

Ideaal is het om ambtsethiek te onderwijzen in de vorm van de Socratische gespreksmethode, tegelijkertijd heeft onderwijservaring mij echter geleerd dat dit veelgevraagd is.

Het incorporeren van aandacht voor ambtsethiek in de diverse vakken vraagt voortdurend bewustzijn van docenten van het belang van die ambtsethiek. Ik realiseer mij dat ook dat veel, en in de praktijk van het universitair onderwijs, vaak te veel gevraagd is. Kennis van de praktijk, kennis van theoretische grondslagen van (ambts)ethiek en dat door de gehele opleiding heen. Toch zal alleen dan het voortdurende bewustzijn over ambtsethiek bij studenten in het beroeps-DNA worden gescherpt en kunnen postvatten. Maar zelfs al zou enkel dat bewustzijn wordt aangekweekt, zou ik al tevreden zijn. De verdere invulling, concretisering, en ook de keuze bij dilemma's, komt dan later wel.

\subsection{Studiemateriaal}

Puur op ambtsethiek toegesneden studiemateriaal voor op de universiteiten is voor het notariaat niet voorhanden. Voor de algemene rechtsethische vorming moeten studenten Notarieel recht het doen met wat hun in het eerste, op algemene vorming gerichte studiejaar wordt voorgeschoteld. Het gaat dan om vakken als Algemene rechtsleer, Encyclopedie van het recht enzovoort. Voor achttienjarigen is dat vaak zware kost, waarin het in de ogen van de student die dan al zijn keuze heeft gemaakt voor Notarieel recht, niet of onvoldoende gaat over het notariaat. Begrijpelijkerwijs worden bij die vakken meer algemene thema's aangesneden, voor een grote gemene deler van studenten. Dat is ook helemaal niet erg als we die (aanstaande) student Notarieel recht maar weten te prikkelen tot verder denken en hem leren dilemma's te herkennen.

In de specifiek op de Notariële studierichting toegesneden studiejaren daarna moet vooral ruimte voor ambtsethiek worden gevonden in vakken als het voornoemde vak Notariële ambtsuitoefening. Ook binnen dat vak moet veel behandeld worden. Het studiemateriaal is dun gezaaid. ${ }^{16}$ Mijns inziens is er zeker plaats voor meer specifiek, op ambtsethiek gericht studiemateriaal, al hoeft dat niet per se in de vorm van een handboek. Werk aan de winkel dus (ik ben aan het broeden). Ondertussen zal, zoals steeds, veel afhangen van de invulling die de docenten eraan weten te geven. De dilemma's liggen voor het oprapen maar je moet daarvoor wel kunnen kijken. komen ethiek en integriteit in bescheiden mate aan de orde. Maar het kan altijd beter. 


\section{De notariële praktijk is om te oogsten}

\subsection{De eerste praktijkjaren}

Als die studenten vervolgens afstuderen en deel gaan uitmaken van het notariaat, wordt het geleidelijk anders. De eerste jaren zullen de nieuwe notareel juristen hun handen vol hebben aan het zich eigen maken van basale vaardigheden en het in de praktijk brengen en uitbouwen van de vakinhoudelijke kennis.

In den beginne is er voor de afgestudeerde jurist Notarieel recht de door de wet voorgeschreven driejarige praktijkopleiding. Het afronden van deze opleiding is een voorwaarde om toegelaten te worden tot de bevoegdheid op te treden als waarnemer van de notaris en om te worden benoemd als toegevoegd notaris en notaris. Binnen de beroepsopleiding kennen we het vak Ethiek, tuchtrecht en beroepshouding. Met drie uur in pakket I en zes uur in pakket II is de voor dit onderwerp ingeruimde tijd schaars. ${ }^{17}$ Doordat de deelnemers in de praktijk werkzaam zijn, zullen zij wel ontvankelijker zijn voor de aandacht die ambtsethiek vraagt.

Bij de cursussen over ambtsethiek zal het van belang zijn omstandigheden te creëren die als veilig worden ervaren, zodat de jonge cursisten zich vrij voelen om hun eerste kantoorervaringen uit te wisselen. Dan kan van de goede ervaringen worden geleerd, maar ook van de slechte, zonder dat er een onmiddellijke dreiging van repercussies is. Naar verwachting zullen cursisten zich spiegelen aan modelkantoren.

\subsection{De jaren des onderscheids}

Als die beroepsopleiding is afgerond, wordt het lastiger om de aandacht voor ambtsethiek te behouden. Verdieping in de vorm van specifiek op ambtsethiek gerichte cursussen is mogelijk. De notarieel juristen zullen in het kader van hun verplichte educatie jaarlijks cursussen moeten volgen. Maar zo die cursussen al specifiek gericht zijn op ambtsethiek, is de keuze om daarop in te tekenen en niet op de zoveelste cursus Actualiteiten, aan de notariële practicus zelf. Er is dus geen verplichting meer om dan nog in de vorm van cursussen aandacht voor ambtsethiek te onderhouden.

\subsection{Instrumenten voor iedere notarieel jurist}

Er zijn leermiddelen die ongeacht de loopbaanfase van een notarieel jurist hun dienst bewijzen. Bij sommige is de beroepsorganisatie KNB nauw betrokken. Als belangrijkste zou ik willen noemen het onderhouden en bevorderen van een esprit de corps, waarin de ambtsdeugden als na te streven doel worden voorgehouden. Uitingen op de website van de $\mathrm{KNB}$, waarmee wordt uitgedragen wat de maatschappij van het notariaat mag verwachten, duwen de notarieel juristen vooruit. Inzichten uit de sociologie kunnen hieraan bijdragen. Het publiek openbaren van ambities en professionele doelstellingen zou soms als gedurfd kunnen worden aangemerkt, want verwachtingen moeten worden waargemaakt, maar noblesse oblige.

Een dapper initiatief in de goede richting, waarbij wordt ingespeeld op de tijdgeest, is de gelikte app die voor notariëlen door de KNB is ontwikkeld, die dillem- 
ma's bevat op het terrein van de ambtsuitoefening. Het gaat hier om een vorm van nudging: het pasklare antwoord wordt niet gegeven, maar de notarieel jurist wordt aan het denken gezet en in de goede richting geleid. Hiervoor worden inzichten uit de psychologie ingezet.

Ook wordt de practicus door de KNB wakker gehouden door een (enkel) preadvies (zoals Lekkerkerker, 2010) of door artikelen in het Notariaat Magazine. Het inmiddels meer dan 150 jaar bestaande Weekblad voor Privaatrecht, Notariaat en Registratie biedt hiervoor ruimte in zijn kolommen en ook de redactie lokt bijdragen op dit gebied uit. ${ }^{18}$

Hoe goedbedoeld deze initiatieven ook zijn, de meest vruchtbare bodem voor reflectie is die van het notariskantoor zelf. Daar zullen de rolmodellen, de 'voorbeeldige notarissen', door georganiseerde reflectie de uiteindelijke oogst binnen kunnen halen. ${ }^{19} \mathrm{Nu}$ immers, zullen de dilemma's onontkoombare praktijk vormen en zal echt kleur moeten worden bekend. In wezen gaat het hier om het aloude model van overdracht van waarden van meester naar gezel. ${ }^{20}$

Regelmatige kantoorlunches vormen mijns inziens ideale een voedingsbodem, waarin het op de universiteit en in de beroepsopleiding met zorg geplante zaadje hopelijk tot volle wasdom komt. Daar wordt onder informele omstandigheden, met een broodje, gesproken over hoe het in een bepaald dossier ging en had moeten gaan. Daar wordt de jurisprudentie van de tuchtrechter besproken. De vaak meer ervaren jurist kan van hieruit zijn beroepshouding, die van de jongere practicus vormen. Ook als die met een enkele vraag aan diens bureau komt 'hoe het verder moet'. Dat gebeurt naar mijn eigen ervaring vaak zonder dat de deelnemende notarieel juristen zich daarvan bewust zijn. Ook daar is winst te behalen: dat bewustzijn kan gekneed en gevormd worden door daar op zichzelf weer aandacht voor te vragen (zie ook Van Oostrum, 2002, door mij besproken in WPNR 03/6544).

Het voortdurend organiseren van dergelijke bijeenkomsten en actieve participatie van de notarissen vraagt het nodige van hen. De leidinggevenden binnen het kantoor en het kantoormanagement zullen hier actief en sturend moeten zijn. Om dit kracht bij te zetten mag ook van de managers worden verwacht dat het niet alléén de door de werknemers gegenereerde omzet is die bepalend is bij het jaarlijks functioneringsgesprek, maar ook de wijze waarop zij invulling geven aan de opdracht van ambtsethisch handelen. Op het gevaar af al te zeer los te zingen van de harde realiteit: wie de economische wetten zal willen gehoorzamen (en welke notaris zal die kunnen negeren?), zou wellicht maatschappelijk verantwoord notareel handelen kunnen uitdragen als reclame-instrument voor zijn kantoor.

18 Zie bijvoorbeeld de Rode draad Goed of fout, min of meer: grip op ethiek en integriteit, die van start ging in WPNR 2017/7154.

19 Over het belang van de voorbeeldige persoon in het kader van de deugdethiek: Van Tongeren, 2008, par. IV.4. Zie ook Laclé, 2008, par. 5.4 en 5.5, die de gang van zaken tijdens kantoorbijeenkomsten illustreert met casus.

20 In een notarieel leerlingcontract uit 1500 las ik: 'En van zijn kant heeft voornoemde meester Bertrandus aan voornoemde Antonius [de leerling, BW] beloofd hem van zichzelve noch de zijnen te verstoten, maar goed en behoorlijk voor hem te zorgen wat betreft voedsel en drank gedurende de bovengenoemde tijd, en Antonius te onderwijzen en te onderrichten in voornoemde wetenschap en verder in al hetgeen behoorlijk is, naar zijn beste kunnen zoals elke goede meester verplicht is zijn dienaren te onderrichten.' Ontleend aan: Pitlo, 1965, hoofdstuk I. 


\subsection{En, werkt het ook?}

Bij dit alles geldt dat deze vanuit het notariaat aangeboden instrumenten zich kenmerken door een zekere vrijblijvendheid. Die geeft ook een zwakte aan. In plaats van dat iemand zich inschrijft voor een cursus ambtsethiek, kan hij nog steeds kiezen voor de cursus 'grensoverschrijdende fusie, splitsing en omzetting'. De tijd die gemoeid is met raadplegen van de app, kan worden gebruikt om te scrollen op internet. En de kantoorlunch kan worden overgeslagen ('druk, druk, druk'). Deze vrijblijvendheid maakt dus alles kwetsbaar. Vanzelfsprekend voelt menig notarieel jurist door de voortwoekerende marktwerking de voortdurende druk kantooromzet te genereren. Ook willen cliënten nu eenmaal alléén betalen voor wat belangrijk is voor hen. Dat ambtsethisch handelen het cliëntbelang overschrijdt en mede het maatschappelijk belang dient, is aan menigeen niet besteed. Ambtsethiek wordt daarbij door cliënten in het beste geval als vanzelfsprekend ervaren, en in het slechtste geval als hinderpaal om te bereiken wat zij willen. Laat ik het voorzichtig zeggen: de hedendaagse consument blijkt veeleisend en is vaak grillig.

Of de genoemde instrumenten ter verbetering van ambtsethiek werken, hangt af van de wil van de individuele beroepsbeoefenaar het goed te doen. Die wil moet van hemzelf komen. De exogene krachten, zoals kantoordiscipline om bij die kantoorlunch aanwezig te zijn, de druk van intercollegiaal toezicht, de KNB, de toezichthouder Bureau Financieel Toezicht (BFT) of de rechter, zijn uiteindelijk mijns inziens slechts noodremmen.

\section{De slotsom: education permanente}

Ambtsethiek verdient aandacht binnen alle fasen van de opleiding en loopbaan van de notarieel jurist. Dat geldt dus ook voor het denkwerk over de vraag hoe die ambtsethiek kan worden gevormd, aangeleerd en onderhouden. Zei Aristoteles al niet dat het bij ethiek gaat om het aanleren van een houding om het goede te doen? Laten we ermee doorgaan ons te verdiepen in de vorming van ambtsethiek! Voor een waardevol notariaat is dit onderwerp te belangrijk om te laten liggen.

\section{Literatuur}

Commissie Evaluatie Wet op het Notarisambt (2005). Het beste van twee werelden.

Heuff, W. (1993). 150 jaar Koninklijke Notariële Broederschap. 25 jaren notariaat in Nederland ter gelegenheid van het 150-jarig bestaan der broederschap op 1 januari 1993 (p. 68).

Kocken, C.L.B. (1997). De hand van de notaris. Een rechtssociologisch onderzoek naar de onpartijdigheid en invloed van de Nederlandse notaris (Dissertatie UvA). Ars Notariatus LXXIX.

Lacklé, Z.D. (2008). Notabelen vernieuwen, Gevolgen van marktwerking in het notariaat (Dissertatie RU Leiden). Ars Notariatus 137.

Lekkerkerker, G.J.C. en Breedveld-de Voogd, C.G. (2010). De goede notaris, Over notariële deontologie. Preadvies Koninklijke Notariële Beroepsorganisatie. Den Haag: Sdu Uitgevers.

Melis/Waaijer (2019). De Notariswet (9de druk). WoltersKluwer.

Oostrum, H.A.J. (2002). Toevallige weetbaarheden. Een onderzoek naar de integriteitsbewaking in advocatenkantoren (Dissertatie, RUU).

Pitlo, A. (1965). Uit oude schrijnen. Ars Notariatus XII. 
Roes, J.S.L.A.W.B. (2017). Notariaat en integriteit. WPNR 2017/7161.

Sandel, M.J. (2010). Rechtvaardigheid, Wat is de juiste keuze? Utrecht: Uitgeverij Ten Have.

Santen, A.H.M. (1992). 150 jaar tuchtrecht. WPNR 92/6054, 466.

Schütz, R. (2016). Kille mist. Het Nederlandse notariaat en de erfenis van de oorlog (Dissertatie, VU Amsterdam).

Soeharno, J. (2020). De moed tot onpartijdigheid, AA oktober.

Stokkermans, Chr.M. (2019). Wat juristen ervan maken. WPNR 2019/7233.

van den Berg-Smit, C. (2013). De gerechtsdeurwaarder: ambtenaar en ondernemer (Dissertatie $\mathrm{UU})$.

van den Boomgaard, P. (2019). Voor de nazi's geen Jood (Dissertatie UvA).

van Domselaar, I. (2017). Moedige juristen in alledaagse context: onbekend en onbemind? WPNR 2017/7175

van Mourik, M.J.A. (2008). Recht, rechtvaardigheid en Ethiek, in het bijzonder in de notariële praktijk, afscheidsrede Radboud Universiteit Nijmegen. WoltersKluwer.

van Tongeren, P. (2008). Deugdelijk leven, een inleiding in de deugdenethiek (4de druk). Nijmegen: SUN.

Waaijer, B.C.M. (2013). Verleiden om te verlijden: Het onmogelijke tweespan van notarieel ambtenaar en vrij ondernemer. WPNR 2013/6990.

Waaijer, B.C.M. (2017a). Hollen of stilstaan? Over het belang van timing in de notariële praktijk. In J.P.M. Stubbe en F.A.M. Schoenmaker (red.). Notamail verklaard. Den Haag: Sdu Uitgevers.

Waaijer, B.C.M. (2017b). Wiens brood men eet, diens woord men spreekt?, Over de verhouding: notaris, overheid en publiek belang. Ars Notariatus 164, par. 6.4.

Waaijer, B.C.M. (2020). Moedige notarissen in de ure des gevaars. WPNR 2020/7286. 